\title{
Indoor Air Quality and Prevalence of Sick Building Syndrome Among Office Workers in Two Different Offices in Selangor
}

\author{
Mohd Ezman Zamani, Juliana Jalaludin and Nafiz Shaharom \\ Department of Environmental and Occupational Health, \\ Faculty of Medicine and Health Sciences, Universiti Putra Malaysia (43400), Serdang, Malaysia
}

Received 2012-10-23, Revised 2013-01-08; Accepted 2013-10-10

\begin{abstract}
This study was done to investigate the relationship between Indoor Air Quality (IAQ) and prevalence of Sick Building Syndrome (SBS) in two different offices (old and new) in Selangor. Hundred and seventy workers were selected consist of 85 office workers for each building. Questionnaire based on Indoor Air Quality and Work Symptoms Survey, NIOSH, Indoor Environmental Quality Survey, 1991 was used to record prevalence of SBS. Measurement of indoor air quality was performed using instruments recommended by IAQ Code of Practice, Department of Occupational Safety and Health, Malaysia. IAQ supplied air was significantly higher in new building with the median $22.49 \mathrm{cfm} /$ person while $15.79 \mathrm{cfm} /$ person in old building $(\mathrm{z}=-6.23, \mathrm{p}<0.001)$. The prevalence of SBS in old building was significantly higher compared to the new building $\left(\chi^{2}=30.6, p<0.001\right)$. Levels of indoor air pollutants in old building were significantly higher compared to new building for: $\mathrm{CO}_{2}(\mathrm{z}=$ -4.62, $\mathrm{p}<0.001)$; TVOC $(\mathrm{z}=-2.71, \mathrm{p}<0.05) ; \mathrm{PM}_{10}(\mathrm{z}=-2.11, \mathrm{p}<0.05) ; \mathrm{PM}_{2.5}(\mathrm{z}=-2.35, \mathrm{p}<0.05)$, meanwhile for UFP $(\mathrm{z}=4.72, \mathrm{p}<0.001)$ and THI value $(\mathrm{z}=-4.57, \mathrm{p}<0.001)$, new building was significantly higher compared to old building. There was significant association between the prevalence of SBS and the indoor air pollutants in the old building namely $\mathrm{CO}_{2}(\mathrm{OR}=3.56,95 \% \mathrm{CI}=1.327-9.548) ; \mathrm{CO}(\mathrm{OR}=4.95,95 \% \mathrm{CI}=1.740-14.127)$; TVOC $(\mathrm{OR}=4.71,95 \% \mathrm{CI}=1.571-14.151) ; \mathrm{PM}_{10}(\mathrm{OR}=6.23,95 \% \mathrm{CI}=2.278-17.065)$ and $\mathrm{PM}_{2.5}(\mathrm{OR}=$ $4.18,95 \% \mathrm{CI}=1.564-11.199)$, while in the new building, the prevalence of SBS showed significant association with an indoor air pollutant namely UFP $(\mathrm{OR}=6.53,95 \% \mathrm{CI}=1.757-24.327)$. After controlling the cofounders; age, medical condition, smoking and having pet at home, the results showed that $\mathrm{CO}_{2}, \mathrm{CO}$, TVOC, $\mathrm{PM}_{10}, \mathrm{PM}_{2.5}$ influenced SBS in old building while UFP influenced SBS in the new building. This study suggested that when there was an increase in the ventilation rates per person in office building, it would significantly reduced prevalence of SBS, even though both buildings meet the existing ASHRAE ventilation standards for office building. Reduction in prevalence of SBS would depend on the increase in ventilation rates, ventilation effectiveness and reduction in indoor air pollutants that can cause SBS.
\end{abstract}

Keywords: Indoor Air Pollutants, Indoor Air Quality (IAQ), New Building, Old Building, Sick Building Syndrome (SBS)

\section{INTRODUCTION}

Nowadays, most of people spent their time up to $80 \%$ in the office equipped with systems such as heating, ventilation and air-conditioning. By having all those systems, it could give thousands of benefits to the workers but from the other sight, the tendency of workers to be exposed to indoor air contaminants is increased which can lead to various type of building illnesses. In addition, the usage of electrical facilities (e.g., computers, photocopy machine or printers) will be an additional factor to increase the exposure among workers to air pollutants. The U.S Environmental Protection Agency (EPA) stated that office workers Corresponding Author: Juliana Jalaludin, Department of Environmental and Occupational Health, Faculty of Medicine and Health Sciences, Universiti Putra Malaysia (43400), Serdang, Malaysia 
spent their time in indoor environment up to $90 \%$ and inadequate ventilation due to the increasing the number of workers in the building leads to sick building syndrome (Apte et al., 2000).

One of well-known health effect resulted from the exposure to indoor air contaminants was sick building syndrome. The sick building syndrome was a major concern as many people were potentially at risk. It was defined by the World Health Organization (WHO) as an excess of work-related irritations of the skin and mucous membranes and other symptoms, including headache, fatigue and difficulty concentrating, reported by workers in modern office buildings. Besides, there were various symptoms that can be seen on those who were very sensitive to moulds which lead to sick building syndrome; eye irritation, nasal stuffiness while some people with chronic lung illnesses such as obstructive lung disease may develop mould infections in their lungs. Other symptoms were cough, tight chest, wheeze and difficulty in breathing (Apte et al., 2000).

Studies have demonstrated that SBS was influenced by the type of ventilation system, with the prevalence of SBS being higher in buildings with mechanical ventilation systems compared to normal ventilation system (Burge et al., 1995). New building normally reported to have high concentration of Total Volatile Organic Compounds (TVOC) while old building recorded poor ventilation rate with the increasing of Carbon Dioxide $\left(\mathrm{CO}_{2}\right)$ level. Inadequate ventilation per occupants and the elevated indoor chemical pollutants concentrations can lead to SBS prevalence (Apte et al., 2000). This study was conducted in order to determine indoor air quality and its association with sick building syndrome among the office workers in two different buildings in Selangor.

\section{MATERIALS AND METHODS}

\subsection{Subject Recruiting and Selection}

To recruit the study subjects, lists of name were obtained from the Human Resource Department in both buildings' office. From the list available, 85 office workers in office at Media Prima Berhad (MPB) building was recruited and categorized under old building group named as Building $\mathrm{A}$. The other 85 office workers, who fulfill the stated criteria and matched as a group, were recruited from Ministry of Energy, Green Technology and Water building as new building group named Building B. All respondents were explained about the procedure of the study and consent letter was obtained from all respondents before the study begins.

This cross-sectional comparative study was conducted between Building A (old building) and Building B (new building). Building A was selected as old building as it was occupied more than 15 years while Building B was considered as new building as it was occupied less than 4 years. These buildings were chosen as both buildings used the same centralized air conditioning system and the offices were completely dependent only on the general ventilation to provide sufficient air for occupants.

\subsection{Socio-demographic Information, Health Status and Prevalence of Sick Building Syndrome}

A set of questionnaires were used to obtain the sociodemographic background of the respondents such as personal information, health status and job position. SBS symptoms questions were based on the Indoor Environmental Quality Survey and Work Symptoms Survey, National Institute Occupational Safety and Health (NIOSH) Indoor Environmental Quality Survey, 1991. The questionnaires asked on worker's health status and symptoms of SBS such as dry and itchy eyes, cough, chest tightness, runny nose and shortness of breath. Zoning of each worker's workstation was categorized accordingly with the reference of floor plan. Reported SBS symptoms were given to the respective respondents on each day of IAQ assessment conducted and the score given in the analysis of data commence. Based on the study by Ooi et al. (1998), building occupants also must report symptoms occurrence of at least 1-3 days per week during four weeks past and the symptoms shown improvement when she/he away from work. Office workers will be defined as having SBS if they had at least one symptom of SBS symptoms and the symptoms appear at least once in a week.

\subsection{Indoor Air Quality Measurements}

Assessment of Indoor Air Quality (IAQ) in Building A and B was conducted according to Malaysia Indoor Air Quality Code of Practice (IAQ, COP), Department of Occupational Safety and Health (DOSH), Malaysia (2005). Duration of each sampling point was $40 \mathrm{~min}$ to represent the selected area and it was depending on the zoning area to the IAQ sampler. Workers closest to the air sampler would be the first priority and the selection continued until the total number of available office workers was achieved. Sampler was located in the center of the location in the office area $75-120 \mathrm{~cm}$ above the ground.

Two instruments were used in order to measure level of indoor air quality; TSI 8554 Q-Trak Plus and TSI 8386 Velocicalc Plus (Velocicalc). The TSI 8554 Q-Trak Plus measure Temperature (Temp), Relative Humidity 
$(\% \mathrm{RH})$, Carbon Dioxide $\left(\mathrm{CO}_{2}\right)$, Carbon Monoxide (CO) and ventilation rate. Concentration of $\mathrm{CO}_{2}$ in this research was used as a ventilation indicator for fresh air supply, supply air from diffuser, return air and outside air. TSI 8386 Velocicalc Plus (Velocicalc) was used to assess air movement, air flow, velocity, volume, pressure different and ventilation rate in both building. Location of all parameters sampling spot was recorded on the layout plan and then all instruments were run simultaneously using specific procedure by IAQ, COP (DOSH, 2005) and ventilation measurement using guideline given by ASHRAE (2001). There were five important variables in this study. For the $\mathrm{CO}_{2}, \mathrm{CO}$, temperature and humidity detection, the TSI 8554 Q-Trak Plus was used. TVOC were recorded by using MiniRAE PGM-7600. For the particulate matter $\left(\mathrm{PM}_{10}\right.$ and $\left.\mathrm{PM}_{2.5}\right)$, the TSI Model 8520 Dust TrakTM Aerosol Monitor and TSI Side PackTM (Side Pack) were respectively used in this study. TSI Model 8525 P-Trak ${ }^{\circledR}$ Ultrafine Particle Counter (UFP) was used in this study to capture UFP concentration on selected location in both buildings.

\subsection{Ethical Issues and Quality Control}

Approval from Medical Researcher Ethic Committee, UPM was obtained. Pre-test of the questionnaire was performed on $10 \%$ of the sample size to maximize the reliability of the questions. All instruments were calibrated before the measurement started and Standard Operating Procedures (SOP) was followed strictly to ensure quality of the data taken by the instruments. All respondents were guided by the researcher himself to avoid any biases that might occur. Standard Code of Practice IAQ by DOSH, Malaysia was used to compare the result from the assessment to ensure the quality of the results.

\section{RESULTS AND DISCUSSION}

\subsection{Socio-Demographic Information}

Table 1 shows the descriptive statistics of the respondents. Percentage of male workers $(56.5 \%)$ was higher compared to female in Building A while percentage of female $(60.0 \%)$ was higher than male in Building B. Malay workers made up the highest percentage in Building A $(60.0 \%)$ as well as in Building $\mathrm{B}(87.1 \%)$. Majority of the respondents were married.

\subsection{Comparison of Indoor Air Quality Supplied Air and Ventilation Measurement}

Indoor Air Quality Supplied Air and Ventilation Measurement were measured by the adequacy of the
IAQ supplied air into the indoor environment in cubic feet minute per person (cfm/person). Carbon dioxide $\left(\mathrm{CO}_{2}\right)$ gas was used as the main indicator for detecting efficiency of supplied air ventilation. Indoor air quality supplied air and ventilation measurement were conducted and measured according to zoning of indoor sampling location. According to ASHRAE (2001), median value of the indoor air quality level was $15 \mathrm{cfm}$ per person. Table 2 shows the differences between $\mathrm{cfm} /$ person levels in both buildings. The result of Mann-Whitney U Test showed Building B had significantly higher indoor air quality supplied air compared to Building A.

\subsection{Comparison of Indoor Air Pollutants in Both Building}

Building B had 17 sampling points while 14 sampling points in the Building A. Normality test were performed and both data were not normally distributed. Building A showed significantly higher parameter of $\mathrm{CO}_{2}$, TVOC, $\mathrm{PM}_{10}$ and $\mathrm{PM}_{2.5}$ compared to Building $\mathrm{B}$. However, the Building $\mathrm{B}$ showed significantly higher UFP concentration and THI values compared to the Building A (Table 3).

Table 1. Socio-demographic characteristics of Building A and Building B respondents

\begin{tabular}{|c|c|c|}
\hline \multirow[b]{2}{*}{ Variables } & \multicolumn{2}{|c|}{ Study groups n (\%) } \\
\hline & $\begin{array}{l}\text { Building A } \\
(\mathrm{n}=85)\end{array}$ & $\begin{array}{l}\text { Building B } \\
(\mathrm{n}=85)\end{array}$ \\
\hline \multicolumn{3}{|l|}{ Sex } \\
\hline Male & $48(56.5)$ & $34(40.0)$ \\
\hline Female & $37(43.5)$ & $51(60.0)$ \\
\hline \multicolumn{3}{|l|}{ Race } \\
\hline Malay & $51(60.0)$ & $74(87.1)$ \\
\hline Chinese & $20(23.5)$ & $1(1.2)$ \\
\hline Indian & $10(11.8)$ & $10(11.8)$ \\
\hline Others & $4(4.7)$ & $0(0.0)$ \\
\hline \multicolumn{3}{|l|}{ Marital status } \\
\hline Married & $73(85.9)$ & $63(74.1)$ \\
\hline Single & $12(14.1)$ & $22(25.9)$ \\
\hline \multicolumn{3}{|l|}{ Education level } \\
\hline Malaysian certificate of education & $0(0.0)$ & $48(56.5)$ \\
\hline Degree & $60(70.6)$ & $32(37.6)$ \\
\hline Master & $8(9.4)$ & $0(0.0)$ \\
\hline Others & $17(20.0)$ & $5(5.9)$ \\
\hline \multicolumn{3}{|l|}{ Smoking status } \\
\hline Never Smoked & $44(51.8)$ & $60(70.6)$ \\
\hline Former Smoker & $6(7.1)$ & $2(2.4)$ \\
\hline Current Smoker & $35(41.2)$ & $23(27.1)$ \\
\hline
\end{tabular}


Table 2. Comparison of the IAQ in Building A and Building B

\begin{tabular}{|c|c|c|c|c|}
\hline \multirow[b]{2}{*}{ Variables } & \multicolumn{2}{|l|}{ Building A $(\mathrm{n}=85)$} & \multicolumn{2}{|c|}{ Building $\mathrm{B}(\mathrm{n}=85)$} \\
\hline & Median (IQR) & Median (IQR) & $\mathrm{z}$ & $\mathrm{p}$ \\
\hline CFM/person & $15.79(13.65-17.31)$ & $22.49(19.81-25.93)$ & -6.230 & $0.001 * *$ \\
\hline
\end{tabular}

**; Significant at $\mathrm{p}<0.001(\mathrm{~N}=170)$

Table 3. Comparison of the concentration of indoor air pollutants between Building A office workers and Building B office workers Median (IQR)

\begin{tabular}{lllll} 
Parameter & Building A $(\mathrm{n}=85)$ & Building B $(\mathrm{n}=85)$ & $\mathrm{z}$ & $\mathrm{p}$ \\
\hline $\mathrm{CO}_{2}(\mathrm{ppm})$ & $704(631-719.5)$ & $456(428-478.5)$ & -4.62 & $0.001^{* *}$ \\
$\mathrm{CO}(\mathrm{ppm})$ & $1.7(1.4-2.1)$ & $1.3(1.1-1.9)$ & -1.63 & 0.102 \\
$\mathrm{TVOC}(\mathrm{ppm})$ & $0.1(0.05-0.2)$ & $0(0.0-0.1)$ & -2.71 & $0.007^{*}$ \\
$\mathrm{UFP}\left(\mathrm{pt} / \mathrm{cm}^{3}\right)$ & $759(621.5-993.5)$ & $1660.5(1556.5-1785)$ & -4.72 & $0.001^{* *}$ \\
$\mathrm{PM}_{10}\left(\mu \mathrm{g} / \mathrm{m}^{3}\right)$ & $57(30.5-73.5)$ & $36.5(26.5-39.25)$ & -2.11 & $0.036^{*}$ \\
$\mathrm{PM}_{2.5}\left(\mu \mathrm{g} / \mathrm{m}^{3}\right)$ & $57(35-70)$ & $37(29.75-41.00)$ & -2.35 & $0.019^{*}$ \\
$\mathrm{THI}\left({ }^{\circ} \mathrm{C} / \mathrm{RH} \%\right)$ & $36.52(33.96-40.57)$ & $49.96(48.16-51.00)$ & -4.57 & $0.001^{* *}$ \\
\hline
\end{tabular}

*: Significant at $\mathrm{p}<0.05 ; * *$ : Significant at $\mathrm{p}<0.001$

\subsection{Prevalence of Sick Building Syndrome (SBS)}

Building A was operated more than 15 years while 4 years for Building B. The score of the SBS had been done according to the positive response, if one symptom recorded nearly every day, the mark given to the SBS scale. If two symptoms reported every day, two score were given and so on (Ooi et al., 1998). As showed in Table 4, number of respondents that had been categorized as having SBS using above criteria given, the Building A recorded $68.2 \%$ office workers having SBS compared to $25.9 \%$ of office workers in the Building.

Based on the results showed from this study (Table 5A and 5B), there was no significant difference in the prevalence of sick building syndrome between high level of indoor air quality and low level of indoor air quality for both buildings. Although there was a significant difference on the level of indoor air quality between the new building and the old building but after the buildings have been separated in order to find the association between the prevalence of SBS and the level of indoor air quality for each building, the results have shown the opposite way.

This result was contradicted with study conducted by Stenberg et al. (1995) who stated that the prevalence of the sick building syndrome would be getting higher among workers who worked in low level of indoor air quality but there was a suspected association between SBS and air humidification, recirculation of exhaust air at high outdoor-air flow rates but not at low outdoor-air flow rates and with natural or mechanical exhaust ventilation systems. According to the ASHRAE Standard 62 for Natural and Mechanical Ventilation, the minimum allowable rates recommended for the office building was $15 \mathrm{cfm} /$ person and since both of the buildings have recorded higher mean value of $\mathrm{cfm} /$ person than the standard, this could be the reason why the significant association between the prevalence of sick building syndrome and the level of indoor air quality could not be obtained.

Similar study has been conducted by Syazwan et al. (2009) who reported that there was a significant association between the prevalence of sick building syndrome and the level of indoor air quality but the main difference was both of the buildings were combined together in order to get the association of it while in this study, the association was determined to each building; Building A and Building B.

From Table 6A, there were five parameters that shown significant associations between the prevalence of sick building syndrome and the indoor air pollutants in Building $\mathrm{A} ; \mathrm{CO}_{2}, \mathrm{CO}$, TVOC, $\mathrm{PM}_{10}$ and $\mathrm{PM}_{2.5}$, while in Building $\mathrm{B}$, there was only one parameter has shown the significant association which was UFP. Similar study has been conducted by Syazwan et al. (2009) that stated $\mathrm{CO}_{2}, \mathrm{CO}$, TVOC and THI have shown significant associations between the prevalence of sick building syndrome and the indoor air pollutants.

Based on the result, there was a significant association between the prevalence of sick building syndrome and $\mathrm{CO}_{2}$ concentration in the Building $\mathrm{A}(\mathrm{OR}=3.56,95 \% \mathrm{CI}$ $=1.327-9.548)$. This showed that the office workers who worked in the office environment with high level of $\mathrm{CO}_{2}$; above $672 \mathrm{ppm}$, have 7.2 times risk likely to develop sick building syndrome than those who worked in the office environment with level of $\mathrm{CO}_{2}$ below than $672 \mathrm{ppm}$. 
Table 4. Comparison of the prevalence of Sick Building Syndrome (SBS) between Building A office workers and Building B office

\begin{tabular}{|c|c|c|c|c|}
\hline \multirow[b]{2}{*}{ Variables } & \multicolumn{4}{|c|}{ Prevalence of SBS N = $170(100 \%)$} \\
\hline & Yes & No & $\chi^{2}$ & $\mathrm{p}$ \\
\hline Building A $\quad(n=85)$ & $58(68.2)$ & $27(31.8)$ & & \\
\hline Building $\mathrm{B}(\mathrm{n}=85)$ & $22(25.9)$ & $63(74.1)$ & 30.6 & $0.001 * *$ \\
\hline
\end{tabular}

**; Significant at $\mathrm{p}<0.001 ; \mathrm{N}=170$

Table 5A. Association of the Prevalence of Sick Building Syndrome with the Level of Indoor Air Quality in Building A

\begin{tabular}{lllll}
\hline & \multicolumn{2}{l}{ Prevalence of SBS N=85 (100\%) } & & \\
Variables & Yes $(\mathrm{n}=58)$ & No $(\mathrm{n}=27)$ & OR & 95\%CI \\
\hline High IAQ level & 30 & 14 & 0.99 & $0.399-2.481$ \\
Low IAQ level & 28 & 13 & & \\
\hline *; OR significant at $95 \% \mathrm{CI}>1$ & &
\end{tabular}

*; OR significant at $95 \% \mathrm{CI}>1$

Table 5B. Association of the Prevalence of Sick Building Syndrome with the Level of Indoor Air Quality in Building B

\begin{tabular}{|c|c|c|c|c|}
\hline \multirow[b]{2}{*}{ Variables } & \multicolumn{4}{|c|}{ Prevalence of SBS N = $85(100 \%)$} \\
\hline & Yes $(n=22)$ & No $(n=63)$ & OR & $95 \% \mathrm{CI}$ \\
\hline High IAQ level & 12 & 31 & 1.23 & $0.468-3.280$ \\
\hline Low IAQ level & 10 & 32 & & \\
\hline
\end{tabular}

Table 6A. Association between Prevalence of Sick Building Syndrome with the Level of Indoor Air Pollutants in Building A

\begin{tabular}{|c|c|c|c|c|c|}
\hline \multirow[b]{2}{*}{ Parameters } & \multirow[b]{2}{*}{ Parameter category } & \multicolumn{4}{|c|}{ Prevalence of SBS N = $85(100 \%)$} \\
\hline & & Yes $(n=58)$ & No $(n=27)$ & OR & $95 \% \mathrm{CI}$ \\
\hline \multirow[t]{2}{*}{$\mathrm{CO}_{2}$} & High & 46 & 14 & $3.56^{*}$ & $1.327-9.548$ \\
\hline & Low & 12 & 13 & & \\
\hline \multirow[t]{2}{*}{$\mathrm{CO}$} & High & 34 & 6 & $4.95^{*}$ & $1.740-14.127$ \\
\hline & Low & 24 & 21 & & \\
\hline \multirow[t]{2}{*}{ TVOC } & High & 30 & 5 & $4.71 *$ & $1.571-14.151$ \\
\hline & Low & 28 & 22 & & \\
\hline \multirow[t]{2}{*}{ UFP } & High & 31 & 9 & 2.29 & $0.886-5.950$ \\
\hline & Low & 27 & 18 & & \\
\hline \multirow{2}{*}{$\mathrm{PM}_{10}$} & High & 42 & 9 & $6.23 *$ & $2.278-17.065$ \\
\hline & Low & 16 & 18 & & \\
\hline \multirow{2}{*}{$\mathrm{PM}_{2.5}$} & High & 37 & 8 & $4.18 *$ & $1.564-11.199$ \\
\hline & Low & 21 & 19 & & \\
\hline \multirow[t]{2}{*}{ THI } & High & 25 & 10 & 1.28 & $0.504-3.291$ \\
\hline & Low & 33 & 17 & & \\
\hline
\end{tabular}

Table 6B. Association between Prevalence of Sick Building Syndrome with the Level of Indoor Air Pollutants in Building B

\begin{tabular}{|c|c|c|c|c|c|}
\hline \multirow[b]{2}{*}{ Parameters } & \multirow[b]{2}{*}{ Parameter category } & \multicolumn{4}{|c|}{ Prevalence of SBS N $=85(100 \%)$} \\
\hline & & Yes $(n=22)$ & No $(n=63)$ & OR & $95 \% \mathrm{CI}$ \\
\hline \multirow[t]{2}{*}{$\mathrm{CO}_{2}$} & High & 9 & 35 & 0.55 & $0.207-1.482$ \\
\hline & Low & 13 & 28 & & \\
\hline \multirow[t]{2}{*}{$\mathrm{CO}$} & High & 8 & 16 & 1.67 & $0.595-4.737$ \\
\hline & Low & 14 & 47 & & \\
\hline \multirow[t]{2}{*}{ TVOC } & High & 8 & 22 & 1.06 & $0.387-2.928$ \\
\hline & Low & 14 & 41 & & \\
\hline \multirow[t]{2}{*}{ UFP } & High & 19 & 31 & $6.53 *$ & $1.757-24.327$ \\
\hline & Low & 3 & 32 & & \\
\hline \multirow{2}{*}{$\mathrm{PM}_{10}$} & High & 15 & 34 & 1.82 & $0.656-5.093$ \\
\hline & Low & 7 & 29 & & \\
\hline \multirow[t]{2}{*}{$\mathrm{PM}_{2.5}$} & High & 14 & 41 & 0.93 & $0.342-2.582$ \\
\hline & Low & 8 & 22 & & \\
\hline \multirow[t]{2}{*}{ THI } & High & 15 & 46 & 0.79 & $0.276-2.276$ \\
\hline & Low & 7 & 17 & & \\
\hline
\end{tabular}

*; OR significant at $95 \% \mathrm{CI}>1(\mathrm{~N}=85)$ 
Other parameter that shown significant association in Building A was CO $(\mathrm{OR}=4.95,95 \% \mathrm{CI}=1.74-14.127)$ and from the result, office workers who worked in the areas with $\mathrm{CO}$ concentration above $1.75 \mathrm{ppm}$ have 8.1 times risk likely to develop sick building syndrome compared to those who were working in the office environment with the level of $\mathrm{CO}$ below than $1.75 \mathrm{ppm}$.

Next, TVOC was one of indoor air pollutants that has shown significant association regarding the association between the prevalence of sick building syndrome and the indoor air pollutants in Building A (OR $=4.71,95 \%$ $\mathrm{CI}=1.571-14.151)$. In this study, it has clearly shown that office workers who worked in areas with TVOC concentration of indoor air environment exceeded 0.124 ppm were approximately had 9.0 times more likely to develop sick building syndrome than office workers who worked in office environments with the level of TVOC concentration below $0.124 \mathrm{ppm}$. The acute effects of the volatile organic compounds were often associated with sick building syndrome and it was a collection of nonspecific symptoms (mucous membrane irritation, skin irritation, fatigue, headache, nausea, poor concentration, rhinitis, wheezing, rashes and other symptoms) often associated with poor indoor air quality (Stolwijk, 1991). In addition, studies in adults have shown an increase in asthma symptoms related to exposure to increased concentrations of VOCs (Norback et al., 1995).

On the other hand, there was a significant difference between the prevalence of sick building syndrome and the level of $\mathrm{PM}_{10}$ concentration in the Building $\mathrm{A}(\mathrm{OR}=$ $6.23,95 \% \mathrm{CI}=2.278-17.065)$. The office workers who worked in office environments with level of $\mathrm{PM}_{10}$ exceeded $53.94 \mathrm{\mu g} \mathrm{m}^{-3}$ would have 7.5 times more likely risk of developing sick building syndrome compared to office workers who worked in areas with level of $\mathrm{PM}_{10}$ concentration below than $53.94 \mu \mathrm{g} \mathrm{m}^{-3}$. Lee and Chang (2000) stated that illegal smoking inside in the building would be the caused of the high concentration of $\mathrm{PM}_{10}$.

The last parameter that has shown the significant association between the prevalence of sick building syndrome and level of indoor air pollutants in the Building A was $\mathrm{PM}_{2.5}(\mathrm{OR}=4.18,95 \% \mathrm{CI}=1.564-11.199)$. From the result, it showed that office workers who worked in the areas with $\mathrm{PM}_{2.5}$ concentration above $53.88 \mu \mathrm{g} \mathrm{m}^{-3}$ have the tendency to develop the sick building syndrome 7.2 times likely compared to those who worked in the office environment with level of $\mathrm{PM}_{2.5}$ below than $53.88 \mu \mathrm{gm}^{-3}$. Studies showed that $\mathrm{PM}_{10}$ for indoor and outdoor air for a wind-induced natural ventilated airspace depended strongly on the ambient particles' distribution and the design of the building openings (Liao et al., 2003) and study conducted by Schwartz and Dockery (1996) stated that particles less than 10 micron and 2.5 micron from any origin can worsen human's heart and induce breathing problem especially to the susceptible group. It was supported by Riediker et al. (2004) who stated that it has been reported that exposure to $\mathrm{PM}_{10}$ and $\mathrm{PM}_{2.5}$ can cause cardiovascular implications on healthy young office workers in North Carolina, US.

Based on the result, there was only one parameter that has shown a significant association between the prevalence of sick building syndrome and level of indoor air pollutants in Building B; UFP, $(\mathrm{OR}=6.53,95 \% \mathrm{CI}=$ 1.757-24.327) (Table 6B). As a result,the office workers who worked in the office environments with level of UFP exceeded $1642.5 \mathrm{pt} / \mathrm{cm}^{3}$ would have the risk of developing sick building syndrome 13.8 times more likely compared to office workers who worked in the areas with level of UFPconcentration below than $1642.5 \mathrm{pt} / \mathrm{cm}^{3}$.

The confounders involved in this study were age, medical condition, smoking and having pets at home and the logistic regression was run in order to get the adjusted value regarding to the association of the prevalence of sick building syndrome and the level of indoor air pollutants. All parameters in the Building A that have shown significant associations were analyzed by using logistic regression in order to control the confounders involved in this study (Table 7A). At this point, the OR for $\mathrm{PM}_{2.5}$ has decreased to 4.117. Although there was a decrement on the value of OR but office workers who worked in the areas with the $\mathrm{PM}_{2.5}$

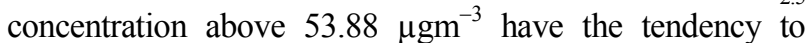
develop the sick building syndrome 8.9 times likely compared to those who worked in the office environment with level of $\mathrm{PM}_{2.5}$ below than $53.88 \mu \mathrm{gm}^{-3}$.

On the other hand, value of OR for $\mathrm{CO}_{2}$ in Building A has increased to 4.744. This turn in has shown that office workers who worked in the areas with $\mathrm{CO}_{2}$ concentration above $672 \mathrm{ppm}$ have the tendency to develop the sick building syndrome 10.8 times likely compared to those who worked in the office environment with level of $\mathrm{CO}_{2}$ below than $672 \mathrm{ppm}$. The result from this study regarding to the indoor air pollutant; $\mathrm{CO}_{2}$, the mean of it was higher compared to previous study conducted by Syazwan et al. (2009). In addition, increasing level of $\mathrm{CO}_{2}$ in each building showed positive association to the occurrences of sick building syndrome thus increases in certain lower respiratory syndrome (Apte et al., 2000).

Carbon monoxide $(\mathrm{CO})$ was the other parameter in the Building A that influenced the prevalence of sick building syndrome in this study. After controlling the confounders; age, medical condition, smoking and having pets at home, the adjusted value gotten has increased to 5.17. This turn in has shown that office workers who worked in the areas with $\mathrm{CO}$ concentration above $1.75 \mathrm{ppm}$ have the tendency to develop sick building syndrome 10.5 times likely compared to those who worked in the office environment with level of $\mathrm{CO}$ below than $1.75 \mathrm{ppm}$. 
Table 7A. Logistic Regression for association between the concentrations of $\mathrm{CO}_{2}, \mathrm{CO}$, TVOC, $\mathrm{PM}_{10}$ and $\mathrm{PM}_{2.5}$ and $\mathrm{SBS}$ among office workers from Building A

\begin{tabular}{llllll}
\hline & & Prevalence of SBS N $=85(100 \%)$ & & \\
Parameters & Parameter category & Yes $(\mathrm{n}=58)$ & No $(\mathrm{n}=27)$ & OR $(95 \% \mathrm{CI})$ & $* \mathrm{OR}(95 \% \mathrm{CI})$ \\
\hline $\mathrm{CO}_{2}$ & High & 46 & 14 & 3.56 & 4.74 \\
& Low & 12 & 13 & $(1.327-9.548)$ & $(1.446-15.561)$ \\
$\mathrm{CO}$ & High & 34 & 6 & $(1.95$ & 5.17 \\
& Low & 24 & 21 & $5.740-14.127)$ & $(1.602-16.743)$ \\
$\mathrm{TVOC}$ & High & 30 & 22 & $(1.571-14.151)$ & $(1.431-20.227)$ \\
& Low & 28 & 9 & 6.23 & 6.29 \\
$\mathrm{PM}_{10}$ & High & 42 & 18 & $(2.278-17.065)$ & $(1.993-19.890)$ \\
$\mathrm{PM}_{2.5}$ & Low & 16 & 8 & 4.18 & 4.11 \\
& High & 37 & 19 & $(1.564-11.199)$ & $(1.373-12.346)$ \\
\hline
\end{tabular}

*; Adjusted OR for age, medical condition, smoking and having pet at home

Table 7B. Logistic Regression for association between the concentrations of $\mathrm{CO}_{2}, \mathrm{CO}$, TVOC, $\mathrm{PM}_{10}$ and $\mathrm{PM}_{2.5}$ and $\mathrm{SBS}$ among office workers from Building B

\begin{tabular}{llllll}
\hline & & Prevalence of SBS N $=85(100 \%)$ & & \\
Parameters & Parameter category & Yes $(\mathrm{n}=58)$ & No $(\mathrm{n}=27)$ & OR $(95 \% \mathrm{CI})$ & $*$ OR $(95 \% \mathrm{CI})$ \\
\hline UFP & High & 19 & 31 & 6.53 & 6.46 \\
& Low & 3 & 32 & $(1.757-24.327)$ & $(1.702-24.576)$ \\
\hline
\end{tabular}

*; Adjusted OR for age, medical condition, smoking and having pet at home

Although there would be a very high tendency of developing sick building syndrome in Building A, but the mean value of $\mathrm{CO}$ concentration was still below the maximum limit, 10 ppm (DOSH, 2005).

Next, the third parameter that has shown significant association with the prevalence of sick building syndrome in the Building A was TVOC. The value of OR has increased to 5.38 and this turn in showed that office workers who worked in the areas with TVOC concentration of indoor air environment exceeded 0.124 ppm were approximately had 14.1 times more likely to develop the sick building syndrome than the office workers who worked in the office environments with level of TVOC concentration below 0.124 ppm.According to DOSH (2005), the maximum limit for the exposure to the TVOC was $3 \mathrm{ppm}$ and the mean value from this study has shown lower value although there would be a high tendency of developing of the SBS symptoms.

The last parameter that has shown significant association regarding to the prevalence of sick building syndrome in the Building A was $\mathrm{PM}_{10}$. After controlling the cofounders, the OR value has increased from to 6.29 and this showed that office workers who worked in the office environments with the level of $\mathrm{PM}_{10}$ exceeded

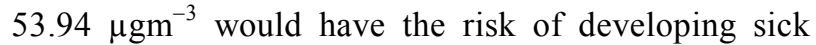
building syndrome 9.9 times more likely compared to the office workers who worked in the areas with level of $\mathrm{PM}_{10}$ concentration below than $53.94 \mu \mathrm{g} \mathrm{m} \mathrm{m}^{-3}$. Particulate matters in the air would be influenced by various factors such as wind-speed, air temperature and relative humidity, atmospheric stability and others (Sham, 1987). In addition, studies showed that $\mathrm{PM}_{10}$ for indoor and outdoor air for a wind-induced natural ventilated airspace depended strongly on the ambient particles' distribution and the design of the building openings (Liao et al., 2003).

In Building $\mathrm{B}$, there was only one parameter that has shown a significant association with the prevalence of sick building syndrome; UFP (Table 7B). The value of OR has decreased to 6.46 and although there was a decrement on the value of the OR but the office workers who worked in the office environments with level of UFP exceeded $1642.5 \mathrm{pt} / \mathrm{cm}^{3}$ would have the risk of developing sick building syndrome 14.4 times more likely compared to the office workers who worked in the areas with the level of UFPconcentration below than $1642.5 \mathrm{pt} / \mathrm{cm}^{3}$. Several studies have shown that ultrafine particles would give higher toxicity compare to larger particles and this was because the ultrafine particles would be able to penetrate deeply into the respiratory tract and due to a large surface area; as a result, it causes greater inflammatory response (Seaton et al., 1995). 


\section{CONCLUSION}

This study suggested that when there was an increase in the ventilation rates per person in office building, it would significantly reduced prevalence of SBS, even though both buildings meet the existing ASHRAE ventilation standards for office building. Reduction in prevalence of SBS would depend on the increase in ventilation rates, ventilation effectiveness and reduction in indoor air pollutants that can cause SBS.

SBS symptoms were significantly associated high level of several indoor air parameters which were carbon dioxide, carbon monoxide, Total Volatile Organic Compound and particulate matters $\left(\mathrm{PM}_{10}\right.$ and $\left.\mathrm{PM}_{2.5}\right)$. Ultrafine particle was a common significant pollutant found in new building and it was a concern as it can also influenced SBS.

Exposure to inadequate supplied air and continuous exposure to indoor air pollutants might elevate risk of getting health problems. Many types of correcting strategies can be recommended to reduce or solve indoor air quality problems. Firstly, regular housekeeping can help to eliminate residues of air pollutants mainly particulate matters either at source or at working station. Prompt clean-up of spills, regular and thorough cleaning of all areas of the office was essential to maintain healthy indoor air.Then, staff should be trained to not doing any activities that can increase level of indoor air pollutants such as smoking in indoor area. Training and advice can help to increase level of consciousness among building occupants on the exposure of indoor air pollutants. Finally, installation of effective ventilation system was essential to maintain healthy indoor air quality. It was to ensure all contaminant can be expelled out efficiently. Recirculation of air containing contaminants to building occupants must also be avoided.

\section{REFERENCES}

Apte, M.G., W.J. Fisk and J.M. Daisey, 2000. Associations between indoor $\mathrm{CO}_{2}$, concentrations and sick building syndrome symptoms in US office buildings: an analysis of the 1994-1996 BASE study data. Indoor Air, 10: 246-257. DOI: 10.1034/j.16000668.2000.010004246.x

ASHRAE, 2001. Ventilation for Acceptable Indoor Air Quality. 1st Edn., American Society of Heating Refrigerating and Air Conditioning Engineers, Atlanta, pp: 34.

Burge, P.S., 1995. Health and built environment. Institute of Environmental, Singapore.
DOSH, 2005. Code of Practice on Indoor Air Quality. 1st Edn., Department of Occupational Safety and Health, Putrajaya, ISBN-10: 9832014514.

Lee, S.C. and M. Chang, 2000. Indoor and outdoor air quality investigation at Schoold in Hong Kong. Chemosphere, 41: 109-113. DOI: 10.1016/S00456535(99)00396-3

Liao, C.M., J.W. Chen and S.J. Huang, 2003. Sizedependent $\mathrm{PM}_{10}$ indoor/outdoor personal relationships for a wind-induced naturally ventilated airspace. Atmospheric Environ., 37: 3065-3075. DOI: 10.1016/S1352-2310(03)00291-7

Norback, D., E. Bjornsson, C. Janson, J. Widstrom and G. Boman, 1995. Asthmatic symptoms and volatile organic compounds, formaldehyde and carbon dioxide in dwellings. Occupat. Environ. Med., 52: 388-395. DOI: 10.1136/oem.52.6.388

Ooi, P.L., K.T. Goh, M.H. Phoon, S.C. Foo and H.M. Yap, 1998. Epidemiology of sick building syndrome and its associated risk factors in singapore. Occupat. Environ. Med., 55: 188-193. DOI: $10.1136 /$ oem.55.3.188

Riediker, M., W.E. Cascio, T.R. Griggs, M.C. Herbst and P.A. Bromberg et al., 2004. Particulate matter exposure in cars is associated with cardiovascular effects in healthy young men. Am. J. Respiratory Critical Care Med., 169: 934-940. DOI: 10.1164/rccm.200310-1463OC

Schwartz, J. and D.W. Dockery, 1996. Is daily mortality associated specically with fine particles? J. Air Waste Manage. Assoc., 46: 927-939. DOI: 10.1080/10473289.1996.10467528

Seaton, A., D. Godden, W. MacNee and K. Donaldson, 1995. Particulate air pollution and acute health effects. Lancet, 345: 176-178. DOI: 10.1016/S01406736(95)90173-6

Sham, S., 1987. Pencemaran Udara. Perspektif Persekitaran, Kuala Lumpur, Dewan Bahasa dan Pustaka.

Stenberg, B. and S. Wall, 1995. Why do women report 'sick building symptoms more often than men? Soc. Sci. Med., 40: 491-502. DOI: 10.1016/02779536(94)E0104-Z

Stolwijk, J.A.J., 1991. Assessment of population exposure and carcinogenic risk posed by volatile organic compounds in indoor air. Risk Anal., 10: 4957. DOI: 10.1111/j.1539-6924.1990.tb01019.x

Syazwan, A. I., J. Juliana, O. Norhafizalina and Z.A. Azman, 2009. Indoor air quality and sick building syndrome in Malaysian buildings. Global J. Health Sci., 1: 126-135. 